\title{
Palaeovalleys in foreland ramp settings: what happens as accommodation decreases down dip?
}

DOI:

10.1111/bre.12200

\section{Document Version}

Accepted author manuscript

Link to publication record in Manchester Research Explorer

\section{Citation for published version (APA):}

Jerrett, R., Flint, S., \& Brunt, R. (2016). Palaeovalleys in foreland ramp settings: what happens as accommodation decreases down dip? Basin Research, 29, 747-774. https://doi.org/10.1111/bre.12200

\section{Published in:}

Basin Research

\section{Citing this paper}

Please note that where the full-text provided on Manchester Research Explorer is the Author Accepted Manuscript or Proof version this may differ from the final Published version. If citing, it is advised that you check and use the publisher's definitive version.

\section{General rights}

Copyright and moral rights for the publications made accessible in the Research Explorer are retained by the authors and/or other copyright owners and it is a condition of accessing publications that users recognise and abide by the legal requirements associated with these rights.

\section{Takedown policy}

If you believe that this document breaches copyright please refer to the University of Manchester's Takedown Procedures [http://man.ac.uk/04Y6Bo] or contact uml.scholarlycommunications@manchester.ac.uk providing relevant details, so we can investigate your claim.

\section{OPEN ACCESS}


1 Palaeovalleys in foreland ramp settings: what happens as accommodation

2 decreases down dip?

3

4 Rhodri M. Jerrett*, Stephen S. Flint, Rufus L. Brunt

5

6 School of Earth, Atmospheric and Environmental Sciences, University of Manchester, Oxford Road,

7 Manchester, M13 9PL, U.K.

8

*Corresponding author: rhodri.jerrett@manchester.ac.uk

Running head: Palaeovalleys in foreland ramp settings.

Key words: Palaeovalley, Foreland Basin, Delta, Sequence Stratigraphy, Central Appalachian Basin, Carboniferous.

Total words: 13,493

\section{ABSTRACT}

Recent advances in our understanding of palaeovalleys are largely guided by examples from passive margins, in which accommodation increases down depositional dip. This study tests these models against a dataset from the Pennsylvanian Breathitt Group of the central Appalachian foreland basin, USA. This fluvio-deltaic succession contains extensive erosionallybased fluvio-estuarine sand bodies that can be tracked over $80 \mathrm{~km}$ down depositional dip from a proximal zone of high accommodation close to the orognic margin to a distal, lower accommodation zone close to the cratonic margin of the basin. The sand bodies are up to $25 \mathrm{~m}$ thick, multi-storey, and characterised in their lower parts by strongly amalgamated storeys containing sandy fluvial to estuarine bar accretion elements, and in their middle to upper parts by more fully preserved storeys up to $10 \mathrm{~m}$ thick and laterally extensive over $100 \mathrm{~s}$ of metres. The upper storeys include abandonment channel-fills of heterolithic marine or marginal marine deposits or muddy to sandy point-bar elements. Three major regional-scale architectures include: (1) Tabular sand bodies that everywhere incise open marine prodelta and mouth bar facies and are interpreted as palaeovalleys formed during falling stage and lowstand systems tracts, when eustatic sea-level fall outpaced tectonic subsidence across the entire study area. (2) Sand bodies that incise genetically related floodplain lake and/or bay-fill minor mouth bar deposits up depositional dip and open marine prodelta and mouth bar facies down dip. These 
stacked distributary channel deposits map down dip into palaeovalleys and formed when up dip subsidence rate resulted in positive, but reduced rate of accommodation creation, while lower tectonic subsidence rate down-dip resulted in incision. (3) Sand bodies that incise genetically related floodplain, lake and/or bay-fill minor mouth bars up dip and pass down-dip into genetically-related unconfined floodplain, prodelta and mouth bar deposits. These sand bodies represent stacked distributary channel fills and channel amalgamation was the product of high rates of lateral migration, typical of the behaviour of channels above their backwater reach. Case (2) sand bodies demonstrate that in rapidly subsiding foreland basins, cross shelf palaeovalleys may form down depositional dip from aggradational, distributive fluival strata. Additionally, the genetic relationship between stacked distributary channels and palaeovalleys supports recent models for palaeovalley formation that emphasise diachronous, cut-and-fill during falling stage and lowstands of relative sea level.

\section{INTRODUCTION}

Since the 1970s, palaeovalleys ("incised valleys") have been the subject of extensive research because their sand-prone fills constitute hydrocarbon reservoirs and their erosional bases were thought to provide the most striking evidence from seismic and outcrop data for sequence boundaries (e.g. Mitchum et al., 1977; Haq et al., 1987; Posamentier \& Vail, 1988; Van Wagoner et al., 1988). Early models for the formation of palaeovalleys implied a scenario in which valleys were cut into older sediment during relative sea-level fall as rivers re-adjusted to lowered shoreline positions, and back-filled during subsequent relative sea-level rise (e.g. Posamentier \& Vail, 1988; Posamentier et al., 1988; Van Wagoner et al., 1990; Shanley \& McCabe, 1994). An incised valley fill was defined as a "fluvially eroded, elongate topographic low that is typically larger than a single channel form, and is characterised by an abrupt seaward shift of depositional facies... at its base" (Zaitlin et al.,1994; Boyd et al.,2006). Since this first generation of sequence stratigraphic models, an increasing volume of publications focusing on the sedimentology and stratigraphy of palaeovalleys (Holbrook \& Wright Dunbar, 1992; Holbrook, 1996; 2001), the geomorphology and dating of Pleistocene to Holocene valley fills (Blum \& Price, 1998; Blum \& Tornqvist, 2000; Tornqvist et al., 2003; Rittenour et al., 2005, 2007; Busschers et al., 2007), flume tank and numerical simulations (Strong \& Paola, 2008), have led to the refinement of genetic models (see recent reviews by Gibling et al., 2011; Holbrook \& Bhattacharya, 2012; Blum et al., 2013). These studies provide an enhanced understanding of the morphological development of palaeovalleys, the nature of their fills and relationship with underlying strata, from an up-dip to down-dip perspective, but are guided significantly by examples of palaeovalleys from continental passive margin shelves, that display a marked 
morphological shelf-break, and where tectonic and gravitationally-driven (growth-fault) accommodation increase down depositional dip (Bond et al.,1995).

In this study, a series of sand bodies encased in marine to terrestrial heterolithic sediments of the middle Pennsylvanian upper Breathitt Group are documented. Many of the channel belts fulfil the traditional definition of palaeovalleys and have been interpreted as such (Aitken \& Flint,1994; Aitken \& Flint,1995). However, the Breathitt Group was deposited in a peripheral foreland basin setting, in which there was no shelf break, and palaeocurrent data indicate the palaeovalleys were carved transversely from the high accommodation orogenic margin towards the low accommodation cratonic margin of the basin (Fig. 1). Thus the upper Breathitt Group provides the opportunity to describe changes in up-dip to down-dip scale, geometry, architecture, formation and evolution of palaeovalleys from a tectonic and geomorphic setting that contrasts markedly with examples derived from continental shelf margins.

\section{RECENT ADVANCES IN STUDIES OF PALAEOVALLEY SYSTEMS}

Blum et al. (2013) advocated a "source-to sink" approach to understanding palaeovalley systems, which provides an useful framework for summarizing current understanding, although their use of nomenclature and case studies implied that the approach applies mainly to passive margins. In this approach, palaeovalleys can be subdivided into three zones, from up-to-down depositional dip: (1) the mixed bedrock-alluvial zone, above the "limit of sea-level influence" and characteristic of continental interiors, where palaeovalleys cut across bedrock or sediment of significantly older age and are long-lived, degradational features; (2) the coastal plain zone, which extends from the "limit of sea-level influence" to the highstand shoreline; and (3) the cross shelf zone, which extends from the position of the highstand shoreline to the continental shelf margin. Palaeovalleys developed in the latter two zones are defined as representing nonequilibrium responses to high frequency sea-level change, in which scouring is generated by fluvial and marine processes, and the palaeovalley fill may include fluvial to shallow marine strata (Blum et al.,2013). The recognition of "mixed bedrock-alluvial palaeovalleys" or palaeovalleys occurring within entirely alluvial facies, clearly nullifies the necessary demarcation of a basinward facies shift at the base of the valley as a defining criterion (Gibling et al.,2011; Blum et al.,2013). In the "coastal plain" and "cross shelf" zones, high-resolution dating of late Pleistocene coastal plain palaeovalley-fills (e.g. Blum \& Tornqvist, 2000; Rittenour et al., 2005, 2007; Busschers et al., 2007), as well as flume tank experiments (e.g. Stong \& Paola, 2008) reveal that during a cycle of sea-level fall and rise, valley-formation is characterised by multiple episodes of fluvial incision, aggradation, and terrace development, such that the basal 
palaeovalley surface is typically generated and covered diachronously during its development. Thus, the erosional base of the preserved palaeovalley-fill in the rock record may resemble a valley in shape and represent a stratigraphic surface that separates older, underlying strata from younger, overlying strata of the palaeovalley-fill, but never itself existed as a geomorphic feature in the palaeo-landscape at any one time (Holbrook \& Bhattacharya,2012; Blum et $a l ., 2013)$. The implication of this more recent understanding is that the basal valley surface likely will not everywhere represent the surface of maximum regression - the sequence boundary - and indeed, the sequence boundary may well be truncated and removed by continued incision during relative sea-level rise. Traditional models (Posamentier \& Vail, 1988; Posamentier et al., 1988; Van Wagoner et al., 1990) tended to depict the palaeovalleys as cutting through previous highstand deposits, clearly defining an unconformity separating genetically unrelated sediments deposited in two different depositional sequences. Although this may hold true for channel incision at the beginning of relative sea-level fall, because the fluvial systems will continue to feed deltaic and shoreface deposits further down-dip on the shelf, continued relative sea-level fall will eventually result in channel incision through their own geneticallyrelated forced regressive deltas. In the cross shelf segment of palaeovalleys, where incisionalaggradational fluvial distributaries eventually pass down dip into distributive, deltaic deposits, the base of the valley will pass down dip from an unconformity into a surface representing the simple incision of distributary channels into their own deposits. Thus, at the time of maximum regression, the sequence boundary will pass down-dip into a depositional surface which downlaps onto the palaeo-sea floor (Martin et al., 2009). From an up-dip (coastal plain) to down-dip (cross-shelf) perspective, the geomorphic expression of palaeovalleys will therefore be increasingly lost, as they experience shorter periods of incision and erosion, and increased marine reworking during transgression.

\section{GEOLOGICAL BACKGROUND}

\section{Tectonic and palaeogeographic setting}

The central Appalachian Basin (Fig. 1) was one of a series of Alleghenian-Variscan peripheral foreland depocentres that developed cratonward of promontories on the Laurasian continental margin (Thomas,1976; Quinlan \& Beaumont,1984). The depocentre was bounded to the west by the Cincinnati Arch (Fig. 1B), and to the east by thrust sheets of the AlleghenianVariscan orogenic belt. To the north, the basin is bounded by the northern margin of a Precambrian basement aulocogen known as the Rome Trough (Tankard, 1986), which at the surface is defined by the Kentucky River Fault System and a series of equivalent faults and 
structures, including the Irvine-Paint Creek Fault Zone (Fig. 1C), that trace northeastward into present-day West Virginia. By the earliest Pennsylvanian, initial phases of thrust sheet emplacement along the southeast margin of Laurasia drove flexural subsidence of the existing cratonic carbonate shelf in an area corresponding to present-day south-eastern West Virginia, and western Virginia (Quinlan \& Beaumont,1984; Tankard, 1986)). This promoted the westward progradation of mud, silt and fine-grained sand sourced from the emerging orogenic belt, conformably over the pre-existing mixed clastic-carbonate shelf into the early basin. Throughout the Pennsylvanian and early Permian, predominantly arkosic siliciclastic debris (subgreywacke) was eroded from the orogenic hinterland to the southeast and transported transversely north-westward through the basin via a succession of deltas (Ferm \& Cavaroc,1968; Ferm, 1970; Horne et al., 1978; Rice et al., 1979; Chesnut,1994), largely considered to have been river-dominated (Englund \& Thomas, 1990; Aitken \& Flint,1995), but also tidally modulated (Martino, 1994; Martino,1996; Greb \& Chesnut, 1996; Adkins \& Eriksson, 1998; Greb \& Martino,2005). During the Lower Pennsylvanian, arkosic sediments were coeval with axial, coarse-grained fluvial and estuarine quartzarenite deposits (Rice et al., 1979; Chesnut, 1992; 1994) derived from the mature craton to the north (Archer \& Greb, 1995; Erikson et al., 2004). Lithospheric flexure towards the orogenic load in the south-east produced a markedly asymmetric basin-fill, characteristic of foreland basins (Allen \& Allen, 2005). The maximum preserved thickness of Pennsylvanian strata in the Central Appalachian Basin is 1.5 km near the Pine Mountain Thrust structure, close to the presumed orogenic margin (Wanless, 1975; Chesnut, 1992; Fig. 1A). Abrupt thinning of the same stratigraphy north of the IrvinePaint Creek Fault Zone has long been recognised (e.g. Arkle, 1974; Greb et al., 2008; Fig 1A). The documentation of "cyclothems"- cyclic, coal-bearing rocks and intervening marine or marine-influenced strata - on the Laurasian continents (Wanless \& Shepard, 1936; Ramsbottom et al., 1978; Ross \& Ross, 1985; Maynard \& Leeder, 1992; Heckel, 1994; Davies et al., 1999; Rygel et al., 2008), and coeval glacial deposits and striated pavements on the Gondwanan continents (Braakman et al., 1982; Audley-Charles, 1984; Caputo \& Crowell, 1985; Veevers \& Powell, 1987; Gonzalez, 2001; Fielding et al., 2008) established that this was a period of large-scale continental glaciation, with associated high-magnitude glacio-eustatic sea-level fluctuations (Veevers \& Powell, 1987; Crowley \& Baum, 1991; Isbell et al., 2003; Rygel et al., 2008). In the central Appalachian Basin, fluvio-deltaic sedimentation was punctuated by regular, cyclic, marine transgressions and periods of subaerial exposure and non-deposition (Wanless, 1939; Chesnut,1994; Aitken \& Flint, 1994; 1995), associated with glacio-eustatically driven rises and falls in sea-level of as much as $100 \mathrm{~m}$ (Rygel et al., 2008). By the late early to mid Permian, during the final phases of the assembly of Pangaea, advancement of the VariscanAlleghenian deformation front subsequently folded and thrusted stratigraphy southeast of the 
position of the Pine Mountain Thrust (Fig. 1C; Miller \& Kent, 1988; Hatcher et al., 1989; Stamatakos et al., 1996). Within the study area, to the northwest of the Pine Mountain Thrust (Fig. 1C), strata are weakly deformed into a major NE-SW striking open fold (the Eastern Kentucky Syncline), with gentle structural dips on the limbs that rarely exceed 10。.

\section{Stratigraphy}

In eastern Kentucky, the late Palaeozoic foreland megasequence of the central Appalachian Basin is broadly a coarsening-up succession of marine, marginal marine and terrestrial clastics, coal and rare carbonate, in which evidence for marine conditions generally decreases upwards (Horne et al., 1978; Chesnut, 1992; Chesnut, 1994). This megasequence can be broadly divided into (1) the lower Breathitt Group, in which subarkosic coal-bearing strata are juxtaposed with thick, quartz-pebble-bearing quartzarenites; (2) the upper Breathitt Group, which contains more laterally continuous coals and lacks quartzarenites; and (3) the Conemaugh Formation, characterised by thinner coals and thicker mudstones (Fig. 2). Chesnut (1992; 1996) formally subdivided the upper Breathitt Group into the Pikeville, Hyden, Four Corners and Princess Formations, bounded by widespread, marine mudstone units - the Betsie Shale, Kendrick Shale, Magoffin and Stoney Fork Members (Fig. 2). Although there is some disagreement about the precise ages of these four major marine units (c.f. Greb et al., 2009), palaeobotanical studies suggest the Betsie Shale and Magoffin members represent the European A. vanderbeckei and $A$. aegiranum ammonoid biozones which define the base and top of the Westphalian B/Duckmanian (c. 315-318 Ma; Gradstein et al., 2012) respectively. Hence, the major marine mudstone units have been interpreted as the maximum flooding zones of 1.5 Ma-duration (third-order sensu Mitchum \& Van Wagoner, 1991) depositional sequences (Aitken \& Flint, 1994; 1995; Greb et al., 2008). Between these formation-bounding marine mudstones, the strata comprise typically 2-15 m thick cycles ("cyclothems") characterised by a locally-toregionally developed marine to marginal marine mudstone which coarsens upward through heterolithic mouth bar and floodplain successions into a regionally extensive coal or coal zone (Fig. 2). Commonly, much or all of the upper part of the cycle may be truncated by major erosionally-based fining-up fluvio-estuarine channel bodies which underlie the regionally extensive coal (Chesnut, 1992; Chesnut, 1994; Aitken \& Flint, 1994; 1995). Chesnut (1992; 1994) and Aitken and Flint $(1994 ; 1995)$ recognised the basin-scale significance of the regional or quasi-regional marine units and coal seams. Hence the cyclothem-scale cycles have been interpreted as parasequence to sequence-scale eustatic cycles superimposed upon the third order eustatic or tectonically-driven accommodation cycles (Chesnut, 1992; 1994), Aitken \& Flint, 1994; 1995). 
This study focuses on the Pikeville and Hyden formations of the upper Breathitt Group.

217 Current biostratigraphic designations of the marine units bounding the Pikeville and Hyden

218 formations (Fig. 2), combined with (undecompacted) isopach data (Fig. 1), suggest that basin

219 subsidence rates at this time, were $>150 \mathrm{~m} /$ Ma on the preserved orogenic margin close to the

220 Pine Creek Thrust, and $<30 \mathrm{~m} /$ Ma on the preserved cratonic margin north of the Irvine-Paint

221 Creek Fault Zone.

222

\section{METHODS AND DATASET}

Extensive road-cut exposures of the Pikeville and Hyden formations were targeted at three locations in eastern Kentucky (Figs. 1C and 3), generated by the recent re-alignment of: (1) U.S. Route 119 between Pikeville and Belfry, Pike County; (2) Kentucky Route 7 between Viper and Jeff, Perry County; and (3) Kentucky Route 15 between Jackson and Vancleve, Breathitt County. The first two locations represent proximal (up-dip), high accommodation sectors of the basin in the foredeep, whereas the Route 15 section represents a more distal, and lower accommodation sector of the basin (Fig. 1C), approximately $80 \mathrm{~km}$ down depositional dip. The Route 15 locations occur just a few kilometres to the south of the Irvine-Paint Creek Fault system, north of which abrup thinning of the Breathitt Group occurs, and should therefore be considered close to, but not on the cratonic margin of the basin. Individual facies and facies associations were described and interpreted and palaeocurrent data collected by means of centimetre-scale sedimentary logging of road cut exposures. Vertical thicknesses were calibrated against road construction engineers' exploration borehole logs, and vertical and lateral stratal relationships at the scale of individual road cut exposures were captured through the annotation of photomosaics (e.g. Fig. 4). Identification of the regionally extensive coal seams and formationbounding major marine members (Chesnut, 1991;1992; Rice \& Hiett, 1994) from published 1:24,000 geological quadrangle maps (Hansen \& Johnston, 1963; Prichard \& Johnston,1963; Puffett, 1964; Alvord, 1965; Wolcott \& Jenkins, 1966; Rice et al., 1977), permitted correlation between road-cut exposures (Fig. 5), and between the proximal and distal sectors of the basin (Fig. 6). Selected road-cuts were targeted for more detailed characterisation of internal sand body architecture (Fig. 7).

\section{FACIES ASSOCIATIONS IN THE PIKEVILLE AND HYDEN FORMATIONS}

A large variety of fully marine to fully terrestrial facies associations (FA) occur in the Pikeville and Hyden formations, but are grouped into eight broad categories for the purpose of this study (summarised in Table 1). The facies associations are tabulated in the context of idealised 
"cyclothems" that have long been described from the upper Breathitt Group (Wanless \& Shepard, 1936; Horne et al., 1978; Chesnut, 1992; 1994; Aitken \& Flint, 1994; Greb et al., 2008). The facies associations are: FA1 - shoreface, FA2 - prodelta, FA3 - mouth bar, FA4 - flood plain, FA5 - mire, FA6 - sandy fluvio-estuarine channels, FA7 - tidal creeks and channels, FA8 - sandy and muddy fluvio-estuarine channels. Bioturbation intensity is typically low, but variable. Characteristics which all facies associations have in common are the pervasive occurrence of sand-grade mica flakes, clay flocks, and rare to abundant, finely commuted plant debris, giving an overall "dirty" appearance to these rocks. Because a continuum of cyclothem thickness from 2-30 m occurs, FA1-5 refer to those elements at the scale of major delta-front progradation, as well as delta-top, or bayhead (valley-filling) sub-delta progradation. FA6-8 refers to those elements which occur both within a deltaic progradational or valley-filling transgressive context.

\section{CORRELATION OF STRATAL TRENDS AND DEPOSITONAL MODEL FOR THE PIKEVILLE AND HYDEN FORMATIONS}

Fig. 6 illustrates the interpreted correlation of stratal trends in the Pikeville and Hyden Formations from the up-dip, high accommodation sectors (Kentucky Route 7 and U.S. Route 119) to the down-dip, low accommodation area (Kentucky Route 15) of the basin. Regional coals and marine to marginal marine units are named following Chesnut (1991) and Rice and Hiett (1994) (Fig. 3). Major sandstones have not traditionally been named in the Breathitt Group, with few notable exceptions (Rice \& Hiett, 1994); Fig. 2). Unless designated a name previously, sandstones are named after the marine to marginal marine member they overlie, for the purpose of clarity (e.g. the Stoney Fork Sandstone overlies the Stoney Fork Marine Member; Fig. 2 and 3). These names do not imply continuity of the sandstone between locations, and are not formally recognised.

Regional vertical trends determined in this study (Fig. 6), illustrate marked thinning of the stratigraphy towards the foreland. These correlations also indicate that the cyclothem-based stratigraphy previously used to define depositional units within the Breathitt Group (e.g. Chesnut, 1992; 1994) is difficult to apply at a regional scale, because of variations in the character of the cyclothems from the up-dip to down-dip areas (Fig. 7). In proximal locations, cyclothems are characterised by a coarsening-up component in which the prodelta (FA2) and mouth bar (FA3) contain rarer marine bioturbation, and relatively abundant transported plant debris. The upper part of the coarsening-up component typically comprises a thicker coal "zone" with intercalated floodplain heteroliths (FA4 and 5). These cylothems are more likely to contain thick, sharp-based fining-up sand bodies comprising fluvial and estuarine channels (FA6-8) and 
the coarsening-up component may be wholly removed by truncation, resulting in sand body amalgamation (Fig. 7). In the distal portion of the basin, cyclothems are characterised by a coarsening-up component in which the prodelta (FA2) and mouth bars (FA3) contain more abundant marine bioturbation, and are capped by a rootlet horizon and thin or absent coal. Large fining-up sand bodies of fluvial and estuarine channels (FA6-8) are notably fewer in the distal sector (Figs. 5, 6 and 7). Thus, evidence for open marine conditions in the succession broadly increases from SE to NW, and these relationships, support previous interpretations of the upper Breathitt Group as broadly representing a succession of transgression-bounded fluvio-deltaic progradation events towards the NW (e.g. Martino, 1994).

The largest-scale transgressions, backstepping of deltaic sedimentation to the SE of the study area, and establishment of regional offshore marine shelf/ramp conditions occurred at the times of the Betsie, Kendrick, and Magoffin marine members (Fig. 6). At the studied sections, coarsening-up packages (bedsets or parasequences) within the Betsie Shale, Kendrick Shale and Magoffin marine member attain thicknesses of up to $30 \mathrm{~m}$ (Fig. 5), setting an absolute minimum (given decompaction) for the maximum water depths attained during these large-scale transgressions. Minor marine or marginal marine successions between the major marine units do not exceed $15 \mathrm{~m}$ thickness, implying waters of this approximate depth or less, during other, more minor transgressions (Fig. 5).

Using the largest preserved storeys as indicative of deposition in trunk distributaries, fluvial style during delta progradation was characterised by large (up to $10 \mathrm{~m}$ bankfull depth) meandering fluvial channels depositing sandy and muddy sediment (FA6). These passed downstream into broader, composite channels containing sandy axially and laterally accreting mid-channel bar-forms (FA7). This interpretation is supported by sand body architecture of normally regressive packages (described below), and the general decrease in abundance of FA6 down depositional dip. An estimate of regional fluvial gradients in the study area can be derived using the relationship between estimated bankfull depth of the largest channels, median bedload grainsize within those channels, the submerged density of the sediment, and assumed bankfull Shields number for nondimensional shear stress. Data from the largest observed channels are utilised, because they more likely represent trunk channels which record the entire system gradient more closely than individual tributaries or distributaries (Holbrook \& Wanas, 2014). Bankfull depth can be estimated for these channels by measuring the height of complete channel abandonment plugs, or complete bar accretion surfaces including top-surface roll over, and expanding by $10 \%$ to account for post-depositional compaction (Ethridge \& Schumm, 1978). Neither complete channel abandonment plugs, nor complete (or truncated) bar accretion surfaces observed in this study exceed $10 \mathrm{~m}$ in thickness (Table 1), suggesting minimum bankfull depths of c. $11 \mathrm{~m}$ for trunk channels in these systems. Median bedload 
grainsize is best represented by the median grainsize of the basal bed or cross-set within a channel-fill or barform (Holbrook \& Wanas, 2014), which is as high as coarse sand in FA7. The submerged density of the original sediment can be estimated from the general detrital composition of subarkosic upper Breathitt Group sediments (from Fu et al., 1994), applying standard densities for quartz and feldspar and assuming a density of $2.7 \mathrm{~g} / \mathrm{cm}^{3}$ for lithic clasts. Finally, bankfull Shields number can be estimated from the observations of Parker (1978), Parker et al. (1998) and Dade \& Friend (1998). Holbrook and Wanas (2014) and Lynds et al., (2014) provide methodologies and error estimates to calculate slope gradients from these estimates. These suggest that absolute maximum equilibrium gradients at lowstands of the largest channels containing the coarsest sediment were in the range 0.00005 (Lynds et al., 2014; method 2) to 0.0003 (Holbrook \& Wanas; 2014). The calculation assumes that these channels were above backwater reach (see below) when the sediment within them was deposited, which was not necessarily the case (Table 1 ).

The backwater length of a river is the distance upstream from confluence with a standing body of water, over which the scoured channel base is at or below lake/sea level. It theoretically represents the course of a channel in which flow will encounter the resistance of the standing body of water, leading to flow deceleration, deposition, and avulsion, and the zone will therefore respond to changes in the relative level of that standing body of water (U.S. Corps of Engineers, 1959; Jerolmack \& Swenson, 2007; Lamb et al., 2012; Nittrouer et al., 2012). The backwater length of a channel is therefore its bankfull depth over its gradient (Paola \& Mohrig, 1996). Taking the fluvial gradients estimated above suggests that major (trunk?) channels in the Pikeville and Hyden formations may have had backwater lengths in the range $40-220 \mathrm{~km}$. When compared to the $80 \mathrm{~km}$ of depositional dip stratigraphy analysed in this study, the lower value of $40 \mathrm{~km}$ for backwater length implies that, irrespective of the position of the shoreline to which any fluvial channels in these formations were attached, at least some of the steeper channels may not have been responding to changes in relative sea-level, across part or most of their length.

The basin-scale extent of marine or marginal marine units, and coal and rootlet zones is indicative of repeated, regional inundation of a broad delta plain followed rapidly by regional terrestrialisation, and the absence of a long-term shelf-slope break within the study area (i.e. a "shelf prism", Patruno et al., 2014), consistent with a foreland ramp setting. This, in part, may explain the difficulty encountered in readily recognising the difference between delta front progradation packages and those representative of bay or lacustrine-fill subdeltas. Recognition that marine to marginal-marine units in the Pikeville and Hyden formations, although laterally extensive in their development, may not represent palaeo-water depths greater that several metres is crucial to the demarcation of basinward facies shift at the bases of palaeovalley-fills, 
particularly given that storey-heights of up to $10 \mathrm{~m}$ are documented within fluvio-estuarine successions (Table 1).

\section{RECOGNITION OF PALAEOVALLEYS IN THE PIKEVILLE AND HYDEN FORMATIONS}

In this study, the descriptive term, sand body refers to a succession of sandy to heterolithic channel-form elements bounded by packages of typically muddy or heterolithic sediment deposited in relatively unconfined settings, irrespective of their genetic type (i.e. palaeovalleyfill or stacked distributary channels), and storeys are defined according to Bridge \& Tye (2000) and Bridge (2003). The absence of otherwise laterally persistent coals or marine-marginal marine units and their replacement by anomalously large thicknesses of sandstone (10 to $25 \mathrm{~m}$, rarely 40 m; e.g. Road Cut 16; Fig. 5A), are indicative of sand body amalgamation. Determining the precise number and original geometries of storeys contained within multi-storey channel sand bodies is difficult, even at single road-cut exposures, because truncation by younger storeys typically removes the upper portions of storeys or entire storeys, and amalgamation commonly obscures storey contacts (Fig. 8). Hence, the statistical significance of stated storey numbers and geometries, below, should be treated with caution.

From detailed analysis of selected multi-storey sand body architectures (Fig. 8), up to eight individual storeys can been recognised at any single road-cut exposure (e.g. Fig. 8B), typically increasing with the cross sectional area of the sand body exposed. Key to recognising palaeovalleys is the requirement for multiple vertically stacked storeys that fill relief greater than the potential height of a single storey (e.g. Ullah et al., 2015). Up to five vertical storeys can be recognised within single sand bodies (e.g. Fig. 8F). Commonly, storey stacking motif is characterised by a lower part comprising multiple extensively amalgamated storeys of sandy fluvial to estuarine channel-form elements (FA6), where storey heights are typically truncated to less than $3 \mathrm{~m}$. These storeys are characterised by basal lags of reworked coal and carbonate and more rarely mudstone and sandstone clasts, and listric normal-faulted olistoliths of underlying prodelta (FA2), mouth bar (FA3) and floodplain (FA4) sediments (Fig. 8). The middle to upper parts of the sand bodies are characterised by better preserved FA6 storeys up to $10 \mathrm{~m}$ thick and laterally extensive over $100 \mathrm{~s}$ of metres. The upper portions of the sand bodies are typically, but not exclusively heterolithic; upper storeys of FA6 becoming abandoned and plugged with siltstone or draped by coal (FA7), or truncated by transgressive tidal creek channel elements (FA7) or sand to muddy fluvial and estuarine channel elements (FA8). The maximum preserved storey thickness of $<10 \mathrm{~m}$, compared to many sand bodies 15-25 m thick suggests many of the latter represent palaeovalleys (e.g. Aiken \&Flint, 1994; 1995). However, in the absence of (exposed) palaeovalley margins, against which internal surfaces can be observed 
407

408

409

410

411

412

413

414

415

416

417

418

419

420

421

422

423

424

425

426

427

428

429

430

431

onlapping and downlapping, a stacked distributary channel origin could also be reasonably argued for many of the sand bodies.

Figures 4 and 5 reveal that fluvio-estuarine sand bodies fall into three distinct classes: (1) regionally tabular sand bodies that everywhere incise offshore prodelta (FA2) and mouth bar facies (FA3); (2) sand bodies that incise genetically related floodplain heteroliths (FA4), lake and/or bay-fill minor mouth bars (FA2 and 3) up dip and offshore prodelta (FA2) and mouth bar (FA3) facies down dip; and (3) sand bodies that incise genetically related floodplain heterolith (FA4), lake and/or bay-fill minor mouth bars (FA2 and 3) in the proximal part of the basin and pass down-dip into unconfined floodplain (FA4), prodelta (FA2) and mouth bar (FA3) deposits. Descriptions and interpretations of selected examples are provided below:

\section{(1) Regionally tabular sand bodies, which everywhere incise offshore prodelta and mouth bar facies}

\section{Description}

This type of sand body is represented by the Elkins Fork Sandstone and Puckett Creek Sandstone (Figs. 5 and 6). Up-dip, along U.S Route 119, the Elkins Fork Sandstone can be traced for $>30 \mathrm{~km}$ along depositional strike. It exceeds $15 \mathrm{~m}$ thickness, comprises at least four vertical storeys at any one road-cut exposure, and incises into offshore prodelta (FA2) and mouth bar (FA3) strata of the underlying Elkins Fork Shale (Fig. 8A). 80 km down-dip, along Ky Route 15, it can be traced for $>8 \mathrm{~km}$ down depositional dip, exceeds $12 \mathrm{~m}$ thickness, comprises at least five vertical storeys at any one exposure, and incises entirely though the Elkins Fork Shale, the Dwale Shale and into to Marine Shale Member H (Fig. 8B). Individual storey heights exceed $8 \mathrm{~m}$ in the proximal and distal part of the basin (Fig. 8A and B).

Up-dip, along U.S Route 119, the Puckett Creek Sandstone (Rice \& Hiett, 1994) can be traced for $>30 \mathrm{~km}$ across depositional strike and for $>2 \mathrm{~km}$ along Ky Route 7 . It exceeds $12 \mathrm{~m}$ thickness, comprises at least four vertical storeys at any one road-cut exposure (Fig. 8C) and comes within $1 \mathrm{~m}$ of entirely removing offshore prodelta (FA2) and mouth bar (FA3) strata of the underlying Kendrick Shale Marine Member (road cut 28; Fig 5B). There is greater than $10 \mathrm{~m}$ of erosional relief on its base. The body contains at least one large abandonment storey up to 9 $m$ thick and filled with floodplain heterolithic facies (FA4; road-cut 31; Fig 5B). Down-dip, along Ky Route 15, the Puckett Creek Sandstone can be traced for $>8 \mathrm{~km}$ down depositional dip, exceeds 10 m thickness, and also comprises at least three storeys (Fig. 8D). It also comes within $1 \mathrm{~m}$ of entirely truncating the underlying offshore prodelta and mouth bar strata of the Kendrick Shale. Individual storey heights exceeding $6 \mathrm{~m}$ are recognised in both up dip and down dip sections (Fig. 8C and D). 
The Elkins Fork Sandstone and Puckett Creek Sandstone everywhere truncate offshore prodelta and distal mouth bar strata of the underlying marine unit, and the Elkins Fork Sandstone in the distal part of the basin completely truncates two underlying marine units. The remarkably tabular geometry and regional extent of both sand bodies (Rice \& Hiett,1994), and of the underlying marine units, suggests their basal surfaces demark a basinward facies shift, and that the sand bodies themselves represent palaeovalley-fills throughout the study area. Both these sand bodies show a consistent number of vertical storeys in up-dip and down-dip locations and the maximum preserved thickness of storeys is also similar in up-dip and down-dip locations. However, both sand bodies are markedly thinner in down-dip locations, implying greater amalgamation of storeys in down-dip locations, which is consistent with a decrease in accommodation in that direction. Furthermore, the truncation by the Puckett Creek Sandstone through the underlying three named marine units demonstrates a deeper unconformity at the palaeovalley base in the distal portion of the basin, also consistent with a decrease in accommodation down depositional dip.

(2) Sand bodies that incise genetically related floodplain thin beds, lake and/or bay-fill minor mouth bars in the proximal part of the basin and offshore prodelta and mouth bar

\section{Description} This type of sand body is represented by sand bodies K and M (Figs. 5 and 6). Up-dip, sand body $\mathrm{K}$ is up to $25 \mathrm{~m}$ thick, contains between at least four vertical storeys (e.g. Fig. 8E), and tapers laterally towards thinly bedded floodplain deposits (road cut 26; Fig. 5A), although the contact is not exposed. The sand body is typically flat-lying above an upper coal of the Fire Clay coal zone but at numerous locations truncates the coal and amalgamates with an unnamed fluvioestuarine sand body within the Fire Clay Coal zone (e.g. between road cuts 11 and 13 and again between 13 and 16; Fig. 5A). At these locations, sand body K may exceed $25 \mathrm{~m}$ thickness, but cannot be differentiated from the underlying sand body. Individual storeys approach $10 \mathrm{~m}$ thickness. Along Ky. Route 7, sand body K exceeds $10 \mathrm{~m}$ thickness, but is discontinuous (road cuts 1, 4 and 5; Fig. 5C) and cannot be traced for more than $2 \mathrm{~km}$. The largest sand bodies at this stratigraphic interval comprise at least 4 vertical storeys each up to $10 \mathrm{~m}$ thick. Where sand body K is absent, multiple 3-5 m cycles of lake or bay-fill mouth bars (FA3) capped by floodplain deposits (FA4; Table 1) thin and fine from the margin of the sand body, and are increasingly tidally reworked towards the NE (road cuts 2 and 3; Fig. 5C). This heterolithic body represents 
the subaqueously deposited levees or crevasse splays genetically related to the sand body. associated with individual storeys within the sand body. Down-dip, on Kentucky Route 15 (Fig. 5D), sand body K is approximately $20 \mathrm{~m}$ thick, and contains at least five vertical storeys up to 10 m thick (Fig. 8F). Here, three successive FA6 storeys contain northerly accreting bar forms, that became abandoned and the channel passively filled with marine strata of FA7. The sand body is incised entirely through offshore mouth bar (FA3) deposits of Marine Member K, and sits flat above a coal belonging to the Fire Clay coal zone.

Up dip, along U.S. Route 119, multiple discrete sand bodies occur at the stratigraphic level of sand body M, each persistent for a maximum of $6 \mathrm{~km}$ (Fig. $5 \mathrm{~A}$ and $\mathrm{B}$ ). These sand bodies have a maximum thickness of at least $18 \mathrm{~m}$, the largest of which comprise at least three storeys in any exposure, incises organic-rich silty lake or bay-fill strata (FA2; e.g. road-cuts 25 and 26; Fig. 5A) and are capped by flood-plain heteroliths (FA4), which become increasingly tidally reworked to the SW. Along Ky. Route 7 the sand body M equivalent extends for $3 \mathrm{~km}$, is up to 25 $m$ thick, and comprises at least three vertical storeys at road cut 4 (Fig. 5C). It lies on the Hamlin coal and at road cut 5 , the faulted margin of the sand body passes laterally into coeval levees (FA4) that fine away to the SW (Fig. 8G). Down dip, along Ky. Route 15, M is encountered only at road cut 5 (Fig. 5D), where it is $20 \mathrm{~m}$ thick, comprises three vertical storeys individually exceeding 7 m thickness, and incises underlying offshore prodelta (FA2) and mouth bar (FA3) strata of Marine Member M (Fig. 8H).

\section{Interpretation}

In the proximal sector of the basin, sand bodies $\mathrm{K}$ and $\mathrm{M}$ are discontinuous, thinning by means of storey number loss, and are incisional into shallow interdistributary bay or lake deposits and capped by floodplain heteroliths. At the margins of both sand bodies, mouth bar and floodplain strata thin and fine away from the sand bodies, suggesting that they are genetically related to the sediment they are incising. At location 5, along Ky. Route 7 (Fig. 5C), the exposure of coeval levees that taper laterally away from a lower storey within the sand body is strongly indicative of unconfined stacking of storeys, and that this composite sand body represents a succession of stacked distributary channels. Therefore, no basinward facies shift can be demonstrated at their bases. It does not follow that all sand bodies at these stratigraphic intervals in the proximal part of the basin must represent stacked channels, rather than palaeovalleys, but the observation that the sand bodies are relatively discontinuous still stands, as does the observation that some proportion of these represent stacked distributaries.

Down dip, sand body K is strongly incisional through an entire offshore mouth bar (FA3) succession whereas sand body M incises offshore prodelta (FA2) and mouth bar (FA3) strata, 
hence demonstrating basinward facies shifts at their bases. There is insufficient exposure to demonstrate the large-scale geometry of sand bodies $\mathrm{K}$ and $\mathrm{M}$ in the distal part of the basin. These sand bodies satisfy the criteria for palaeovalley-fills in their down dip reaches but represent stacked distributary (possibly also tributary) channels incising shallow water and terrestrial strata in their up-dip reaches.

\section{(3) Sand bodies that incise genetically related floodplain deposits, lake and/or bay-fill} minor mouth bars in the proximal part of the basin and pass down-dip into unconfined floodplain, prodelta and mouth bar deposits

\section{Description}

This category includes a large number of sand bodies from single storey channels to large, $25 \mathrm{~m}$ thick sand bodies comprising at least four vertical storeys. These are not named on Figs. 5, 6 and 8 , for clarity. The sand bodies are best illustrated by the interval between the Whitesburg and Fire Clay Coal zones (Fig. 8I and J). At this level multiple sand bodies, one containing at least four vertical storeys, up to $10 \mathrm{~m}$ thick, occur. These sand bodies are amalgamated with more regionally distributed sand bodies to form composite sand bodies nearly $40 \mathrm{~m}$ thick. Down dip, these sand bodies are absent, and the stratigraphic interval is represented by condensed successions of bay or lacustrine prodelta (FA2), mouth bar (FA3) and floodplain strata (FA4; Fig. 6).

\section{Interpretation}

Although they may amalgamate locally to form some of the largest composite sand bodies observed in this study, these sand bodies are relatively laterally discontinuous and commonly incise floodplain heteroliths. Packages of floodplain heterloiths that thin and fine away from these sand bodies suggests that they may represent genetically related levees and crevasse splay deposits coeval with these distributaries. The absence of these sand bodies in the down dip part of the basin, and their replacement by successions of bay or lacustrine prodelta, mouth bar and floodplain strata can be explained through distributive processes, characteristic of fluvio-deltaic sedimentation: the systematic bifurcation of distributaries, and distribution of sediment via overbanking and crevasse-splaying, resulting in the downstream decrease in storey size and amalgamation (Olariu \& Bhattacharya, 2006; Weissmann et al., 2010), and described in numerous examples where fluvial systems cross foreland basins transversely (e.g. Nichols \& Hirst, 1998; Fontana et al., 2014; Kukulski et al., 2013; Owen et al., 2015).

\section{DISCUSSION}


540 Two end-member sand body styles occur within the Pikeville and Hyden formations. The Elkins

541 Fork and Puckett Creek sand bodies represent strongly amalgamated tabular palaeovalley sand

542 bodies throughout the study area (Fig. 6), with width/thickness ratios greatly exceeding 1000.

543 These width/thickness ratios greatly exceed those of any dated Pleistocene to Holocene

544 palaeovalleys in the compilation of Blum et al. (2013). Hence, they are interpreted as a

545 succession of amalgamated palaeovalleys that represent multiple episodes of regional subaerial

546 exposure, erosion and aggradation. Within the individual component palaeovalleys, the cut and

547 fill of individual storeys were likely diachronous events that occurred throughout the falling

548 stage and lowstand systems tracts (Holbrook \& Bhattacharya, 2012; Blum et al., 2013). Thus, for

549 two reasons, the sand body bases are not considered to everywhere constitute isochronous

550 sequence boundaries.

551 The other end member sand body type are the large number of multi storey sand bodies 552 that represent simple stacked distributary channels that thin and fine down depositional dip 553 (Fig. 6; Olariu \& Bhattacharya, 2006; Weissmann et al., 2010). Although these bodies can form 554 laterally extensive sand belts up-depositional dip (Fig. 5), the recognition of genetically related 555 levees and crevasse deposits on the margins of the sand bodies, and the absence of these sand 556 bodies down depositional dip suggest that they represent distributary channels developed 557 during normal fluvio-deltaic progradation. Width/thickness ratios in these sand bodies are 558 typically less than 1000 which, although lower than the strongly amalgamated tabular 559 palaeovalley sand bodies that exist throughout the whole study area, are still much higher than 560 width/thickness ratios of 70-300, considered usual of amalgamated distributive sand bodies by 561 Blum et al. (2013). Up dip amalgamation is considered as due to low rates of aggradation, and 562 high rates of lateral migration, typical of the behaviour of channels above their backwater reach. 563 This scenario is plausible given calculated backwater lengths as short as $40 \mathrm{~km}$. Sediment input 564 was able to keep pace with accommodation in the proximal part of the basin, but insufficient 565 sediment supply inhibited progradation of channel sand bodies to the down-dip sector (i.e. Ky. 566 Route 15 in Breathitt County) in the studied part of the basin (c.f. Fig. 8I and J).

567 Between these end-members, sand bodies $\mathrm{K}$ and $\mathrm{M}$ in the Hyden Formation, and 568 possibly the Frozen Sandstone in the Pikeville Formation represent stacked distributary 569 channels up-dip and palaeovalley-fills down-dip (Fig. 6). These sand bodies represent 570 progradation to aggradation up-dip, passing down-dip to areas that experienced base-level fall, 571 degradation and valley formation. This relationship can also be explained in a foreland basin 572 setting in which tectonic accommodation is greatest in the proximal part of the basin, and 573 decreases away from the source of sediment towards the foreland. Following normal 574 progradation of the delta plain across the breadth of the basin, an episode of modest eustatic 
sea-level fall may be suppressed by the rate of subsidence in the proximal part of the basin, retaining accommodation, whilst simultaneously outpacing slower tectonic subsidence close to the cratonic margin of the basin, resulting in accommodation destruction and palaeovalley formation. The width/thickness ratio of these sand bodies at down-dip locations are $>1000$, and at up dip locations $<1000$ - greater than what Blum et al. (2013) considered usual for either palaeovalleys or stacked distributaries. It is proposed that down-dip these sand bodies represent multiple laterally amalgamated palaeovaleys, whereas up-dip, these episodes were represented by low rates of aggradation and significant lateral migration, resulting in the formation of laterally extensive composite sand bodies.

Fig. 9 depicts this scenario during a single transit of eustatic sea-level fall and rise in a foreland basin in which the fluvio-deltaic systems prograde transversely. The resulting stratal stacking patterns can be contrasted with the idealised stratal stacking patterns generated during an equivalent sea-level cycle on a passive margins (Vail et al., 1977). Note that in this model, valley incision is depicted by multiple episodes of fluvial incision, aggradation, and terrace development, rather than by a single episode of incision followed by later back-filling. The model builds on concepts depicted in Lawton et al. (2014), but with significantly greater displacement of the shoreface. The descriptive sequence stratigraphic nomenclature of Neal and Abreu (2009) is applied.

At the time of maximum rates of eustatic sea-level rise (Fig. 9A), the majority of the foreland basin may be transgressed by marine conditions, and deltaic sedimentation confined to the orogenic margin of the basin. Towards the craton, clastic sedimentation will be condensed, and sea-level may be high enough to transgress the zone of non-subsidence/uplift on the forebulge crest. Following maximum flooding, the rate of eustatic sea-level rise will begin to fall. Combined eustatic and tectonic accommodation close to the orogenic margin may initially remain sufficiently high to result in aggradation or weak progradation of the deltas cratonward. Delta top facies will be dominated by large volumes of preserved crevasse splay, levee, lake and bay-fill deposits, and distributary channel fills will be isolated. Thick, stacked distributary channel sands may form close to the input location of a major river into the basin, grain size, storey size and amalgamation will decrease down-dip as distributaries bifurcate. However, as the rate of eustatic sea-level rise continues to slow total accommodation reduces and the deltas will prograde at an increased rate towards the cratonic margin (Fig. 9B). Fluvial systems may prograde sufficiently to cross the entire breadth of the basin and meet the tectonically stable or uplifting cratonic margin. Distributary channel sands will increasingly amalgamate as a result of the decreased rate of accommodation generation (Fig. 9B). Stratal stacking patterns up-dip will be marked by thick aggradational to progradational successions (aggradation-progradation). Down-dip, deposition will initially be marked by condensation, until up-dip deltas are able to 
prograde. Hence stacking patterns down-dip will be marked by a thin aggradational (condensed) package, followed by thin, highly progradational package (aggradationprogradation).

As eustatic sea-level begins to fall, it will be suppressed by high tectonic subsidence close to the orogenic margin, and sediment is still accommodated in that zone (Fig. 9C). In the medial to distal portion of the basin, tectonic subsidence will not keep pace with eustatic sea level fall, resulting in subaerial exposure and erosion of previously deposited delta top, shoreface and delta front successions. The agents of this erosion will be the antecedent progradational fluvial and deltaic distributaries, which now become tributive, degradational, and valley-forming (Fig. 9C). Up-dip, stratal stacking patterns will remain progradational, whereas down-dip, stacking patterns will be degradational. This scenario makes an interesting prediction: if highstand sea-level was sufficiently high to allow the non-subsiding/uplifting craton to be crested by deltaic progradation (i.e. a short lived "forebulge depocentre" or equivalent; c.f. DeCelles \& Giles, 1996), then mixed bedrock-alluvial palaeovalleys may carve transversely through the craton and carry excess sediment into the neighbouring depocentre. Thus, stacked distributaries, would pass down-dip into cross-shelf palaeovalleys, in turn passing farther down-dip into mixed alluvial-bedrock palaeovalleys. However, if deltaic progradation did not crest the subsiding/uplifting craton, then residual topography would prohibit the formation of transverse mixed bedrock-alluvial palaeovalleys on the craton, and valley-forming fluvial systems would be deflected axially in a bid to locate accommodation. Temporal and spatial interactions between transverse and axial fluvial systems have been documented in other foreland basin systems (e.g. Kukulski et al., 2013; Lawton et al., 2014; Szwarc et al., 2015). At this stage the actively accommodating orogenic margin of the basin would effectively be isolated from marine influence, deposition would therefore more properly be termed "fluvial", and palaeovalleys would pass up-dip (orogen-ward) into proximal trunk distributaries (Fig. 9C). Finally, slowly falling, stillstand, then slowly rising base-level will result in increasing rates of total accommodation near the orogenic margin of the basin, extending with time towards the cratonic margin (Fig. 9D). Carving of palaeovalleys will continue on the exposed cratonic margin of the basin, but their fill may become increasingly estuarine until open marine conditions encroach (axially?) up the basin. Up-dip, the resulting stacking patterns will be progradational-aggradational. Down dip, stacking patterns will be degradational-aggradationalretrogradational.

The predicted stratal architecture in this model, aggradation-progradation-aggradation up-dip, and aggradation-progradation-degradation-aggradation-retrogradation down-dip (Fig. 9D), is borne out by observations in the Pikeville and Hyden formations: the up-dip orogenic margin has a greater tendency towards thick, aggradational fluvial to delta top (lake and bay-fill 
647 and distributary channel) successions, where distributary channel size decreases cratonward as 648 a result of distributive processes; close to the cratonic margin there is a greater tendency 649 towards offshore and delta front successions sharply incised by amalgamated, multi storey 650 palaeovalley sand bodies (Fig. 6). Within the basin, palaeovalleys developed during a single 651 cycle of sea-level fall and rise, pass up-dip into a broadly conformable succession of delta fluvial 652 to delta top strata, and theoretically could pass down-dip into mixed bedrock-alluvial 653 palaeovalleys (with poor preservation potential) on the craton. This contrasts strongly with the 654 up-dip to down-dip evolution of palaeovalleys in passive margin settings, from mixed alluvial655 bedrock, to coastal plain to cross-shelf, to correlative conformity envisaged by Blum et al. 656 (2013).

657 The down-dip transformation of stacked distributaries to palaeovalley-fills in sand 658 bodies $\mathrm{K}$ and $\mathrm{M}$ therefore provides a rare documented example of a down dip transition from 659 Type 2 to Type 1 sequence boundary in fluvio-deltaic strata, as envisaged by Posamentier \& 660 Allen (1993). In shallow marine settings the Type 2 sequence boundary is marked by a 661 turnaround in parasequence stacking pattern from progradational to aggradational to retrogradational (Vail et al., 1977; Van Wagoner et al., 1990) and has been documented in other high subsidence settings (e.g. Howell et al., 1996). In a fluvio-deltaic succession it would be most 664 likely represented by an accommodation minimum, marked by a maximum degree of channel 665 amalgamation without major incision. As discussed, maximum storey amalgamation occurs 666 close to the bases of sand bodies throughout the Pikeville and Hyden formations, irrespective of 667 their origin, but there is no observed evidence in this study for distinct surfaces within sand 668 bodies $\mathrm{K}$ and $\mathrm{M}$ that would represent the Type 2 sequence boundary. Furthermore, the 669 recognition of Type 2 sequence boundaries in the proximal, high accommodation sector of 670 foreland basins will be difficult as the sequence stratigraphic signal will become increasingly 671 masked by the occurrence of large distributive channels close to their input point into the basin. 672 In principle, the Type 2 sequence boundary will occur somewhere within the stacked channel 673 sandbodies, whereas the traditional approach to sequence stratigraphy would place a Type 1 674 sequence boundary at the base of palaeovalley sand bodies (e.g. Posamentier \& Vail, 1988; 675 Posamentier et al., 1988; Van Wagoner et al., 1990; Aiken\& Flint, 1995; Shanley \& McCabe, 676 1994). Attempting to correlate the sequence boundary in sand bodies which record the down677 dip passage from stacked distributary channels to palaeovalley-fills, as in this study, highlights 678 the mismatch between the interpretation of where the Type 2 sequence boundary should occur 679 within a sand body, and where the Type 1 sequence boundary was traditionally placed, since 680 the surface would effectively have to "jump" down from within the sand body to its base, at the 681 transformation point from staked distributary channels to palaeovalley-fill. More recent models 682 for valley formation, emphasising the diachronous nature of the basal palaeovalley surface 
683 (Strong \& Paola, 2008; Gibling et al.,2011; Blum et al.,2013) are supported by this theoretical 684 observation.

685 Because the position of net accommodation destruction will gradually migrate orogen686 wards, and then craton-wards during any sinuous cycle of sea-level fall and then rise, there will 687 be a theoretical maximum limit to the position up-dip "head wall" of the palaeovalley. Is it 688 possible to recognise this position within sand bodies? Given the well-established difficulty 689 encountered in discriminating stacked distributary channels from palaeovalley fills at outcrop, 690 it is unlikely that this theoretical scour could be readily discerned from underlying and 691 overlying normal distributary channel erosion surfaces. Regional analysis of sand body external 692 and internal geometries may, however, provide an indication as to the approximate position of 693 this point. In the Pikeville and Hyden formations the sand bodies displaying the greatest 694 regional basinward facies shifts at their bases (i.e. the Elkins Fork and Puckett Creek 695 Sandstones), display an extraordinarily tabular geometry at basin-scale (width/thickness $696>1000$, possibly approaching 5000). Internally, however, storeys are subtly less amalgamated 697 up-dip (Fig. 8A-D), reflecting an up-dip increase in accommodation. Palaeovalleys that pass up698 dip into stacked distributary sandstones (the K and M sand bodies) display a markedly more 699 lenticular, isolated geometry and less amalgamation up dip than the Elkins Fork and Puckett 700 Creek palaeovalley-fills (width/thickness <1000). Hence, within a single sand body, regional 701 analysis of its geometry (becoming increasingly lenticular, with less storey amalgamation up 702 dip), provides evidence for a down-dip decrease in accommodation, and tendency to switch 703 from distributive to valley-fill character. This will contrast with distributive sand bodies which will show a tendency for increased amalgamation and increased storey thickness up depositional dip (Olariu \& Bhattacharya, 2006; Weissmann et al., 2010), thus providing key criteria to aid in the application of sequence stratigraphy in fluvio-deltaic foreland basin settings.

\section{CONCLUSIONS}

The Pikeville and Hyden formations provide a database for understanding the down dip changes in character of fluvio-deltaic systems that prograded from the high subsidence orogenic margin towards the low subsidence cratonic margin of the central Appalachian peripheral foreland basin. This situation differs from sequence stratigraphic templates dominated by passive margin models in which subsidence rate increases basinward. Down dip correlation for $80 \mathrm{~km}$, based on mapped coal seams and marine shale units, indicates three major regional architectural styles: (1) Regionally tabular palaeovalley-fill sand bodies, which demonstrate everywhere a basinward facies shift at their bases, and were generated when eustatic sea-level 
fall outpaced tectonic subsidence across the study area, and low accommodation resulted in channel amalgamation. (2) Stacked distributary channels that pass laterally into genetically related floodplain heterolithic, lake and/or bay-fill minor mouth bars up dip and pass down-dip into palaeovalley-fills that demonstrate a basinward facies shift at their bases. These bodies formed during episodes of modest sea-level fall, which was suppressed by high tectonic subsidence rate in the proximal part of the basin; the same eustatic fall outpaced the tectonic subsidence rate close to the cratonic margin of the basin, resulting in antecedent fluvial distributaries becoming tributive and valley-forming. (3) Stacked distributary channel sand bodies that incise genetically related floodplain strata, lake and/or bay-fill deposits up-dip and pass down-dip into unconfined floodplain, prodelta and mouth bar deposits. These represent simple normal regressive delta successions.

The down-dip passage over $80 \mathrm{~km}$ from stacked distributary channels to cross shelf palaeovalleys in this asymmetric foreland basin setting, contrasts with the up-dip to down-dip evolution of palaeovalleys in passive margin settings, from mixed alluvial-bedrock, to coastal plain to cross-shelf, to correlative conformity, as envisaged by Blum et al. (2013). Additionally, the down-dip transformation of stacked distributaries to palaeovalley-fills provides a rare documented example of the down dip translation from a Type 2 to a Type 1 sequence boundary within fluvio-deltaic strata. In similar scenarios, where transverse fluvial or fluvio-deltaic systems prograde from a zone of high accommodation to low accommodation, it may be possible to differentiate palaeovalley sand bodies from stacked distributaries by the tendency for the sand body to become increasingly lenticular in external geometry up depositional dip, with a lower degree of internal storey amalgamation.

\section{ACKNOWLEDGEMENTS}

This project was funded by Statoil. The authors are especially indebted to S. Greb for introduction to the exposures, extensive and fruitful discussions and continued hospitality. The authors also thank the assistance of L. Bennie, W. Bower, A. Dawson, C. Eble, H. Falcon-Lang, M. Gugliotta, W. Head and M. Jones in data collection and/or discussion of the work. Data for the isopaching in Fig. 1 are available online thanks to the Kentucky Geological Survey. J. Koldingsnes and $\emptyset$. Spinnangr are thanked for the imagery in Fig. 4, and A. Hughes aided in the drafting of Fig. 6. Reviews and suggestions from J. Bhattacharya, M. Blum, and Basin Research Associate Editor S. Castelltort, enormously enhanced the quality of this paper. The views expressed in the paper are, however, the authors' alone.

\section{REFERENCES}


ADKINS, R.M. \& ERIKSSON, K.A. (1998) Rhythmic sedimentation in a mid-Pennsylvanian deltafront succession, Magoffin Member (Four Corners Formation; Breathitt Group), Eastern Kentucky: a near complete record of daily, semi-monthly and monthly tidal periodicities. In: Tidalites: Processes and Products (Ed. by C.R. Alexander, R.A. Davies \& V.J. Henry), SEPM Spec. Pub., 61, 85-94.

AITKEN, J.F. \& FLINT, S.S. (1994) High-frequency sequences and the nature of incised valley-fills in fluvial systems of the Breathitt Group (Pennsylvanian), Appalachian foreland basin, eastern Kentucky. In: Incised Valley Systems: Origin and Sedimentary Sequences, SEPM Spec. Pub., 51, 353-368.

AITKEN, J.F. \& FLINT, S.S. (1995) The application of high-resolution sequence stratigraphy to fluvial systems: a case study from the Upper Carboniferous Breathitt Group, eastern Kentucky, USA, Sedimentology, 42, 3-30.

Allen, P.A. \& ALLEN, J.R. (2005) Basin Analysis - Principles and Applications, Blackwell Publishing. Oxford, pp. 549.

ALVORD, D.C. (1965) Geologic Map of the Broad Bottom Quadrangle, Eastern Kentucky, U.S. Geological Survey, 7.5-Minute Geological Quadrangle Map, GQ-442.

ARChER, A.W. \& GReB, S.F. (1995) An Amazon-scale drainage system in the eraly Pennsylvanian of central North America, J. Geol., 103, 611-627.

ARKLE, T. (1974) Stratigraphy of the Pennsylvanian and Permian Systems of the Central Appalachians. In Carboniferous of the Southeastern United States (Ed. by G. Briggs), Geological Society of America Special Paper, 148, 5-29.

Audley-Charles, M. (1984) Cold Gondwana, warm Tethys and the Tibetan Lhasa block, Nature, 310, 165.

Blum, M., Martin, J., Milliken, K. \& Garvin, M. (2013) Paleovalley systems: Insights from Quaternary analogs and experiments, Earth Sci. Rev., 116, 128-169.

BLUM, M.D. \& PRICE, D.M. (1998) Quaternary alluvial plain construction in response to glacioeustatic and climatic controls, Texas Gulf coastal plain. In Relative Role of Eustasy, Climate and Tectonism in Continental Rocks (Ed. By K.W. Shanley, and P.J. McCabe), SEPM Spec. Pub., 59, 31-48.

BLuM, M.D. \& ToRnQVIST, T.E. (2000) Fluvial responses to climate and sea-level change: a review and look forward, Sedimentology, 47, 2-48.

Bond, G., KominZ, M.A. \& SHERIDAN, R.E. (1995) Continental terraces and rises. In: Tectonics of Sedimentary Basins (Ed. by C. Busby, \& R. Ingersoll, R.), pp. 149-178, Blackwell Science, Oxford. 
BOYD, R., DALRYMPLE, R.W. \& ZAITLIN, B.A. (2006) Estuarine and incised-valley facies model. In: Facies Models Revisited (Ed. by H.W. Posamentier, \& R.G. Walker), SEPM Spec. Pub., 84, 171-235.

BraAkman, J.H., Levell, B.K., Martin, J.H., PotTer, T.L. \& VAnlivet, A. (1982) Late Paleozoic Gondwana glaciation in Oman, Nature, 299, 48-50.

BRIDGE, J.S., 2003, Rivers and Floodplains: Forms, Processes, and Sedimentary Record. Oxford, U.K., Blackwell Science Ltd., 491 p.

BRIDGE, J.S., AND TYE, R.S. (2000) Interpreting the dimensions of ancient fluvial channel bars, channels, and channel belts from wireline-logs and cores, Am. Assoc. Petroleum Geol. Bull., 84, 1205-1228.

Busschers, F.S., KasSe, C., VAn Balen, R.T., VANDEnBerghe, J., Cohen, K.M., WeERTS, H.J.T., WALLINGA, J., JOHNS, C., ET AL. (2007) Late Pleistocene evolution of the Rhine-Meuse system in the southern North Sea basin: imprints of climate change, sea-level oscillation and glacio-isostacy, Quat. Sci. Rev., 26, 3216-3248.

CAPUTO, M.V. \& CROWELL, J.C. (1985) Migration of glacial centers across Gondwana during Paleozoic era, Geol. Soc. Am. Bull., 96, 1020-1036.

CHESNut, D.R. (1991) Paleontological Survey of Pennsylvanian Rocks of the Eastern Kentucky Coal Field, Series. Kentucky Geological Survey Information Circular (Series 36), Lexington, Ky. CHESNUT, D.R. (1992) Stratigraphic and Structural Framework of the Carboniferous Rocks of the Central Appalachian Basin, Kentucky Geological Survey Bulletin (Series 3), Lexington, Ky. CHESNUT, D.R. (1994) Eustatic and tectonic control of the lower and middle Pennsylvanian strata of the central Appalachian Basin. In: Tectonic and Eustatic Controls on Sedimentary Cycles (Ed. by J.M. Dennison, \& F.R. Ettensohn), SEPM Concepts in Sedimentology and Paleontology 4, 25-34.

ChESnUt, D.R. (1996) Geologic framework for the coal-bearing rocks of the Central Appalachian Basin, Int. J. Coal Geol., 31, 55-66.

CORPS OF ENGINEERS (1959) Backwater Curves in River Channels. Engineering Manual 11102-1408, U.S. Army, Washington D.C.

CRowley, T.J. \& BAUM, S.K. (1991) Estimating Carboniferous sea-level fluctuations from Gondwanan ice extent, Geology, 19, 975-977.

DADE, W.B., \& FRIEND, P.F. (1998) Grain-size, sediment transport regime, and channel slope in alluvial rivers, J. Geol., 106, 661-675.

DAvies, S.J., HAMPSON, G.J., Flint, S.S., ElliotT, T.E. \& ATKInSON, C.D. (1999) Continent-scale sequence stratigraphy of the Upper Carboniferous and its applications to reservoir prediction. In: Petroleum Geology of Northwest Europe: Proceedings of the 5th Conference (Ed. by A.J. Fleet \& S.A Boldy), The Geological Society of London, 757-770. 
DECelLES, P.G. \& GILES, K.A. (1996) Foreland basin systems, Basin Research, 8, 105-123.

EnGLund, K.J. \& Thomas, R.E. (1990) Late Paleozoic depositional trends in the central Appalachian Basin U.S., Geological Survey Bulletin, 1839, F1-F19.

ERIKSON, K.A., CAMPBELL, I.H., PALin, J.M., AlLEN, C.M. \& BoCK, B. (2004) Evidence for multiple recycling in neoproterozoic through Pennsylvanian sedimentary rocks of the central Appalachian Basin, J. Geol., 112, 261-276.

ETHRIDGE, F.G., AND SCHUMM, S.A., 1978, Reconstructing paleochannel morphologic and flow characteristics: methodology, limitations, and assessment. In: Fluvial Sedimentology (Ed. By A.D. Miall), Canadian Society of Petroleum Geologists, Memoir 5, p. 703-722.

FERM, J.C. (1970) Allegheny deltaic deposits - deltic sedimentation, modern and ancient, SEPM Spec. Pub., 15, 312.

FERM, J.C. \& CAVAROC, V.V. (1968) A nonmarine sedimentary model for the Allegheny rocks of West Virgina. In: Late Paleozoc and Mesozoic Continental Sedimentation, Northeastern North America (Ed. by G. de V.G. Klein.), Geol. Soc. Am. Spec. Paper 106, 1-19.

Fielding, C.R., FranK, T.D., BirgenheIER, L.P., RYgel, M.C., JoNES, A.T. \& RoBERTS, J. (2008) Stratigraphic imprint of the Late Palaeozoic Ice Age in eastern Australia: a record of alternating glacial and nonglacial climate regime, J. Geol. Soc., 165, 129-140.

FONTANA, A., MOZZI, AP, MARCHETTI, M. (2014) Alluvial fans and megafans along the southern side of the Alps, Sed. Geol., 301, 150-171.

FU, L., MILLIKEN, K.L. \& SHARP, J.M. (1994) Porosity and permeability variations in fractured and liesegang-banded Breathitt sandstones (Middle Pennsylvanian), eastern Kentucky: diagenetic controls and implications for modeling dual-porosity systems, J. Hydrol., 154, 351-381.

GiBlinG, M.R., FIELDinG, C.R. \& SinHA, R. (2011) Alluvial valleys and alluvial sequences: towards a geomorphic assessment. In: From River to Rock Record: The Preservation of Fluvial Sediments and Their Subsequent Interpretation (Ed. by C.P. North), SEPM Spec. Pub. 97, 423-447.

GonZaLEZ, C.R. (2001) New data on the Palaeozoic glaciations in Argentina, Newsletter on Carboniferous Stratigraphy, 19, 44-45.

Gradstein, F.M., OGG, J.G., SchmitZ, M.D. \& OGG, G.M. (2012) The Geologic Time Scale, Elsevier, Oxford, U.K.

GREB, S.F. \& CHESNUT, D.R. (1996) Lower and lower Middle Pennsylvanian fluvial to estuarine deposition, central Appalachian basin: Effects of eustasy, tectonics, and climate, Geol. Soc. Am. Bull., 108, 303-317.

GREB, S.F., CheSNUT, D.R. \& EblE, C.F. (2004) Temporal changes in coal-bearing depositional sequences (Lower and Middle Pennsylvanian) of the central Appalachian Basin, U.S.A. In: 

Coal-Bearing Strata: Sequence Stratigraphy, Paleoclimate, and Tectonics (Ed. by J.C. Pashin \& R. Gastaldo) Am. Assoc. Pet. Geol. Studies in Geology, 98-120.

Greb, S.F., Chesnut, D.R., Eble, C.F. \& BlaKe, B.M. (2009) The Pennsylvanian of the Appalachian Basin. In: Carboniferous Geology and Biostratigraphy of the Appalachian Basin (Ed. by S.F. Greb, \& D.R. Chesnut), Special Publication of the Kentucky Geological Survey, 32-45.

GREB, S.F. \& MARTINO, R.L. (2005) Fluvial-estuarine transitions in fluvial-dominated successions: examples from the Lower Pennsylvanian of the central Appalachian Basin. In: Spec. Pub. of the International Association of Sedimentologists 35, 425-452.

GREB, S.F., PASHin, J.C., MARTino, R.L. \& EBLE, C.F. (2008) Appalachian sedimentary cycles during the Pennsylvanian: Changing influences of sea-level, climate and tectonics. In: Resolving the Late Palaeozoic Ice Age in Time and Space (Ed. by C.R. Fielding, T.D. Frank, \& J.L. Isbell), Geological Society Special Paper 441, 235-248.

HANSEN, W.R. \& JoHNSTON, J.E. (1963) Geology of the landsaw Quadrangle, Kentucky, U.S. Geological Survey, 7.5-Minute Geological Quadrangle Map, GQ 201.

HAQ, B.U., HARDENBOL, J. \& VAIL, P.R. (1987) Chronology of fluctuating sea levels since the Triassic, Science, 235, 1156-1167.

Hatcher, R.D., Thomas, W.A., Geiser, P.A., Snoke, A.W., Mosher, S. \& Wiltschko, D. V. (1989) Alleghanian Orogen. In: The Appalachian-Ouachita Orogen in the United States (Ed. by R.D. Hatcher, W.A. Thomas, \& G.W. Viele) Geological Society of America, Geology of North America, Boulder, Co., F2, 233-318.

HECKEL, P.H. (1994) Evaluation of field evidence for glacio-eustatic control over marine Pennsylvanian cyclothems in North America and consideration of possible tectonic effects. In: Tectonic and Eustatic Controls on Sedimentary Cycles (Ed. by J.M. Dennison, \& F.R. Ettensohn), 65-87.

HOLBROOK, J.M. (1996) Complex fluvial response to low gradients at maximum regression: A genetic link between smooth sequence-boundary morphology and architecture of overlying sheet sandstone, J. Sed. Res, 66, 713-722.

HOLBROOK, J.M. (2001) Origin, genetic interrelationships, and stratigraphy over the continuum of fluvial channel-form bounding surfaces: An illustration from middle Cretaceous strata, southeastern Colorado, Sed. Geol., 124, 202-246.

HOLBROOK, J.M. \& BHATTACHARYA, J.P. (2012) Reappraisal of the sequence boundary in time and space: Case and considerations for an SU (subaerial unconformity) that is not a sediment bypass surface, a time barrier, or an unconformity, Earth Sci. Rev., 113, 271-302.

HOLBROOK, J. \& WANAS, H. (2014) A fulcrum approach to assessing source-to-sink mass balance using channel paleohydrologic paramaters derivable from common fluvial data sets with an example from the Cretaceous of Egypt, J. Sed. Res, 84, 349-372. 
HOLBROOK, J.M. \& WRIGHT DUNBAR, R. (1992) Depositional history of Lower Cretaceous strata in northeastern New Mexico: Implications for regional tectonics and depositional sequences, Geol. Soc. Am. Bull., 104, 802-813.

Horne, J.C., Perm, J.C., CARUCCiO, F.T. \& BAGAnZ, B.P. (1978) Depositional models in coal exploration and mine planning in Appalachilan Region, Am. Assoc. Petroleum Geol. Bull., 62, 2739-2411.

HowELL, J.A., FLINT, S.S. \& HUNT, C. (1996) Sedimentological aspects of the Humber Group (Upper Jurassic) of the South Central Graben, UK North Sea, Sedimentology, 43, 89-114.

IsBelL, J.L., LENAKER, P. A., ASKIN, R. A., MilLER, M.F. \& BABCOCK, L.E. (2003) Reevaluation of the timing and extent of late Paleozoic glaciation in Gondwana: Role of the Transantarctic Mountains, Geology, 31, 977.

JEROLMACK, D.J. \& SWENSON, J.B. (2007) Scaling relationships and evolution of distributary networks on wave-influenced deltas, J. Geophys. Res., 34, L23402.

KUKULSKI, R. B., HUBBARD, S. M., MOSLOW, T. F., \& RAINES, M. K. (2013) Basin-scale stratigraphic architecture of upstream fluvial deposits: Jurassic-Cretaceous foredeep, Alberta Basin, Canada, J. Sed. Res., 83, 704-722.

LAMB, M.P., NITTROUER, J.A., MOHRIG, D. \& SHAW, J. (2012) Backwater and river plume controls of scour upstream of river mouths: implications for fluvio-deltaic morphodynamics, J. Geophys. Res. 117, F01002.

LAWTON, T.F., SCHELLENBACH, W.L. \& NUGENT, A.E. (2014) Late Cretaceous fluvial-megafan and axial-river systems in the southern Cordilleran foreland basin: Drip Tank Member of Straight Cliffs Formation and adjacent strata, southern Utah, USA, J. Sed. Res., 84, 407434.

LYNDS, R.M., MOHRIG, D., HAJEK, E.A. \& HELLER, P.L. (2014) Paleoslope Reconstruction In Sandy Suspended-Load-Dominant Rivers. Journal of Sedimentary Research, 84, 825-836. MACEACHERN, J.A. (2010) Ichnology and facies models. In: Facies Models 4 (Ed. by N.P. James, \& R.W. Dalrymple), pp. 19-58, Geological Association of Canada.

Martin, J., Paola, C., Abreu, V., Neal, J. \& SheETS, B. (2009) Sequence stratigraphy of experimental strata under known conditions of differential subsidence and variable base level, Bull. Can. Petrol. Geol., 4, 503-533.

MARTINO, R.L. (1994) Facies analysis of Middle Pennsylvanian marine units, southern West Vrigina. In: Elements of Pennsylvanian Stratigraphy, Central Appalachian Basin (Ed. by C.L. Rice), Geol. Soc. Am. Special Paper 294, 69-86.

MARTINO, R.L. (1996) Stratigraphy and depositional environments of the Kanawha Formation (Middle Pennsylvanian ), West Virginia, Int. J. Coal Geol., 31, 217-248. 
MAYNARD, J.R. \& LEEDER, M.R. (1992) On the periodicity and magnitude of late Carboniferous glacioeustatc sea-level changes, J. Geol. Soc., 149, 303-311.

MiLLER, J.D. \& KENT, D. V. (1988) Regional trends in the timing of Alleghanian remagnetization in the Applachians, Geology, 70, 131-147.

Mitchum, R.M. \& WAGONER, J.C. VAN (1991) High-frequency sequences and their stacking patterns: sequence-stratigraphic evidence of high-frequency eustatic cycles, Sed. Geol., 70, 131-147, 153-160.

Mitchum, R.M., VAIL, P.R. \& THOMPSON III, S. (1977) Seismic stratigraphy and global changes of sea level, part 2: the depositional sequence as a basic unit for stratigraphic analysis. In: Seismic Stratigraphy - Applications to Hydrocarbon Exploration (Ed. by C. Payton), Am. Assoc. Petrol. Geol. Memoir 26, 53-62.

NEAL, J. \& ABREU, V. (2009) Sequence stratigraphy hierarchy and the accommodation succession method, Geology, 37, 779-782.

NICHOLS, G. J. \& HIRST, J. P. (1998) Alluvial fans and fluvial distributary systems, Oligo-Miocene, northern Spain: contrasting processes and products, J. Sed. Res, 68, 879-889.

NITTROUER, J.A., SHAW, J., LAMB, M.P., MOHRIG, D. (2012) Spatial and temporal trends for water-flow velocity and bed-material sediment transport in the lower Mississippi River, Geol. Soc. Am. Bull. 124, 400-414.

OLARIU, C. \& BHATTACHARYA, J.P. (2006) Terminal distributary channels and delta front architecture of river-dominateddelta systems, J. Sed. Res, 76, 212-233.

OWEN, A., NICHOLS, G., HARTLEY, A. J. \& WEISSMANN, G. (2015) Vertical trends within the prograding Salt Wash distributive fluvial system, SW USA, Bas. Res., in press.

PATRUNO, S., HAMPSON, G. J. \& JACKSON, C. A.-L. (2015) Quantitative characterisation of deltaic and subaqueous clinoforms, Earth Sci. Rev., 142, 79-119.

PAOLA, C. \& MOHRIG, D. (1996) Palaeohydraulics revisited: palaeoslope estimation in coarsegrained braided rivers, Basin Res. 8, 243-254.

PARKER, G. (1978) Self-formed rivers with stable banks and mobile bed: Part I, the sand-silt River. J. Fluid Mech., 89, 109-126.

PARKER, G. \& CUI, Y. (1998) The arrested gravel front: stable gravel-sand transitions in rivers: Part 1. Simplified analytical solution, J. Hydraul. Res., 36, 75-100.

POSAMENTIER, H.W. \& ALLEN, G.P. (1993) Variability of the sequence stratigraphic model: effects of local basin factors Sed. Geol., 86, 91-109.

PosamentieR, H.W. \& VAIL, P.R. (1988) Eustatic control on clastic deposition II - sequence and system tract models. In: Sea-Level Changes: An Integrated Approach (Ed. by C.K. Wilgus, B.S. Hastings, C.G.C. Kendall, H.W. Posamentier, C.A. Ross, \& J.C. Van Wagoner), SEPM Spec. Pub. $42,125-154$. 
Posamentier, H.W., JerVey, M.T. \& VAiL, P.R. (1988) Eustatic controls on clastic deposition I conceptual framework. In: Sea-Level Changes: An Integrated Approach (Ed. by C.K. Wilgus, B.S. Hastings, C.G.C. Kendall, H.W. Posamentier, C.A. Ross, \& J.C. Van Wagoner), SEPM Spec. Pub. 42, 109-124.

PRICHARD, G.E. \& Johnston, J.E. (1963) Geology of the Jackson Quadrangle, Kentucky, U.S. Geological Survey, 7.5-Minute Geological Quadrangle Map, GQ 205.

PUFFETT, W.P. (1964) Geology of the Hazard South Quadtrangle, Kentucky, U.S. Geological Survey, 7.5-Minute Geological Quadrangle Map, GQ 343.

Quinlan, G.M. \& BEAUMONT, C. (1984) Appalachian thrusting, lithospheric flexure, and the Paleozoic stratigraphy of the eastern interior of North America, Can. J. Earth Sci., 21, $973-$ 996.

Ramsbottom, W.H.C., Calver, M.A., Eagar, R.M.C., Hodson, F., Holliday, D.W., STUbBlefield, C.J. \& WILSON, R.B. (1978) A Correlation of Silesian Rocks in the British Isles, Geological Society of London Special Report 10.

RICE, C.L. \& HIETT, J.K. (1994) Revised correlation chart of coal beds, coal zones and key stratigraphic units in the Pennsylvanian rocks of eastern Kentucky, U.S. Geological Survey Miscellaneous Field study, 1 sheet.

RICE, C.L., PING, R.G. \& BARR, J.L. (1977) Geologic Map of the Belfry Quadrangle, Pike County, Kentucky, U.S. Geological Survey, 7.5-Minute Geological Quadrangle Map, GQ1369.

Rice, C.L., Sable, E.G., Dever, JR., G.R. \& Kehn, T.M. (1979) The Mississippian and Pennsylvanian (Carboniferous) systems in the United States - Kentucky, U.S. Geological Survey Professional Paper 1110-F, F1-F32.

RitTenour, T.M., Goble, R.J. \& Blum, M.D. (2005) Development of an OSL chronology for Late Pleistocene channel belts in the lower Mississippi valley, USA, Quat. Sci. Rev., 24, 25392554.

RitTenour, T.M., Blum, M.D. \& Goble, R.J. (2007) Fluvial evolution of the lower Mississippi River valley during the last 100 k.y. glacial cycle: Response to glaciation and sea-level change, Geol. Soc. Am. Bull., 119, 586-608.

Ross, C.A. \& Ross, J.R.P. (1985) Late Paleozoic depositional sequences are synchronous and worldwide, Geology, 13, 194-197.

Rygel, M.C., FIELDing, C.R., Frank, T.D. \& BirgenheIER, L.P. (2008) The Magnitude of Late Paleozoic Glacioeustatic Fluctuations: A Synthesis, J. Sed. Res, 78, 500-511.

SHANLEY, K.W. \& MCCABE, P.J. (1994) Perspectives on the sequence stratigraphy of continental strata, Am. Assoc. Petroleum Geol. Bull., 74, 544-568.

StAmatakos, J., HiRT, A.M. \& LOWRIE, W. (1996) The age and timing of folding in the central Appalachians from paleomagnetic results, Geol. Soc. Am. Bull., 108, 815-829. 
STONG, N. \& PAOLA, C. (2008) Valleys that never were: time surfaces versus stratigraphic surfaces, J. Sed. Res, 78, 579-593.

SZWARC, T.S., JOHNSON, C.L., STRIGHT, L.E., \& MCFARLANE, C.M. (2015) Interactions between axial and transverse drainage systems in the Late Cretaceous Cordilleran foreland basin: Evidence from detrital zircons in the Straight Cliffs Formation, southern Utah, USA, Geol. Soc. Am. Bull., 127, 372-392.

TANKARD, A.J. (1986) Depositional response to foreland deformation in the Carboniferous of eastern Kentucky, Am. Assoc. Petroleum Geol. Bull., 70, 853-868.

TAYLOR, A.M. \& GOLDRING, R. (1993) Description and analysis of bioturbation and ichnofabric, J. Geol. Soc., 150, 141-148.

ThomAS, W.A. (1976) Evolution of the Ouachita-Appalachian continental margin, J. Geol., 84, 323-342.

TORNQVIST, T.E., WALLINGA, J., \& BUSSCHERS, F.S. (2003) Timing of the last sequence boundary in a fluvial setting near the highstand shoreline-insights form optical dating, Geology, 31, 279-282.

ULLAH, M., BHATTACHARYA, J.P., AND DUPRÉ, W.R. (2015) Confluence Scours versus Incised Valleys: Examples from the Cretaceous Ferron Notom Delta, SE Utah, J. Sed. Res. 85, 445458.

Vail, P.R., Mitchum, R.M.J., Todd, R.G., Widmier, J.M., Thomson, S.I., SAnGREe, J.B., BubB, J.N. \& HATELID, W.G. (1977) Seismic stratigraphy and global changes of sea-level. In: Seismic Stratigraphy - Applications to Hydrocarbon Exploration (Ed. by C. Payton), Am. Assoc. Pet. Geol. Studies in Geology 27, 49-212.

Van Wagoner, J.C., Posamentier, H.W., Mitchum, R.M., Vail, P.R., SARG, J.F., Loutit, T.S. \& HARDENBOL, J. (1988) An overview of sequence stratigraphy and key definitions. In: SeaLevel Changes: An Integrated Approach (Ed. by C.K. Wilgus, B.S. Hastings, C.G., Kendall, H.W. Posamentier, C.A., Ross, \& J.C. Van Wagoner, J. C.), SEPM Spec. Pub. 42, 39-45.

VAn Wagoner, J.C., Mitchum, R.M., CAmpion, K.M. \& Rahmanian, V.D. (1990), Siliciclastic Sequence Stratigraphy in Well Logs, Cores, and Outcrops: Concepts for High-Resolution Correlation of Time and Facies, Am. Assoc. Pet. Geol. Methods in Exploration.

VEEVERS, J.J. \& PowELL, C.M. (1987) Late Paleozoic glacial episodes in Gondwanaland reflected in transgressive-regressive depositional sequences in Euramerica, Geol. Soc. Am. Bull., 98, $475-487$.

WANLESS, H.R. (1939) Pennsylvanian correlations in the Eastern Interior and southern Appalachian coal fields, Geol. Soc. Am. Special Paper, 17, 130. 
WANLESS, H.R. (1975) Appalachian region. In: Paleotectonic Investigations of the Pennsylvanian System in the United States (Ed. by E.D. McKee, \& E.J Crosby), U.S. Geological Survey Professional Paper 853, 17-62.

WANLESS, H.R. \& SHEPARD, F.P. (1936) Sea level and climatic changes related to late Paleozoic cycles, Geol. Soc. Am. Bull., 47, 1177-1206.

Weissmann, G.S., HARTley, A.J., Nichols, G.J., SCUderi, L.A., Olson, M., Buehler, H. \& BANTEAH, R. (2010) Fluvial form in modern continental sedimentary basins: Distributive fluvial systems, Geology, 38, 39-42.

WolcotT, D.E. \& JENKInS, E.C. (1966) Geologic Map of the Meta Quadrangle, Pike County, Kentucky, U.S. Geological Survey, 7.5-Minute Geological Quadrangle Map, GQ-497.

ZAITLIN, B.A., DALRYMPLE, R.W. \& BOYD, R. (1994) The stratigraphic organization of incised-valley systems associated with relative sea-level change. In: Incised Valley Systems: Origin and Sedimentary Sequences (Ed. by R.W. Dalrymple, R. Boyd, \& B.A. Zaitlin), SEPM Spec. Pub. 51, 45-60.

\section{FIGURE, TABLE AND SUPPLEMENTARY MATERIAL CAPTIONS}

Fig. 1. (a) Location of map (b) in the contiguous U.S.A. (b) Location of the preserved Pennsylvanian-early Permian succession of the greater Appalachian Basin, and frontal thrust of the Alleghanian Orogeny. (c) Outcrop map of the Breathitt Group in eastern Kentucky, showing isopach of the combined Pikeville and Hyden formations. The locations of the three targeted study areas are highlighted, as well as histograms illustrating all palaeocurrent data collected from the Pikeville and Hyden formation along Kentucky Route 15 and US Route 11. Mean vector, $\mathrm{m}$, and number of readings, $\mathrm{n}$, indicated. Details of the construction of the isopach maps are provided in Supplementary Material Table 1.

Fig. 2. (a) Chronostratigraphy and lithostratigraphy of the Pennsylvanian foreland basin succession of the central Appalachian Basin in eastern Kentucky. Based on data from Greb et al. (2008), but recalibrated to the timescale of Gradstein et al. (2012). Abbreviations: AC Fm. = Alvy Creek Formation; BC Fm. = Bottom Creek Formation; BR Sst. = Bee Rock Sandstone; WP Sst. = Warren Point Sandstone; S Sst. = Sewanee Sandstone; (b) Named coals, marine-marginal marine shale members and fluvio-estuarine sandstones of the Pikeville and Hyden formations. Shale Members are officially designated (Chesnut, 1992), but sandstones terminology is unofficial, and proposed in this study. Locally developed coal seams are shown with dashed lines (from Rice \& Hiett, 1994). Locally developed shale members, or members where definitive evidence for marine conditions is lacking, are shown in hatched grey (from Chesnut, 1991 and Rice \& 
Hiett, 1994). The width of the speckled boxes corresponds to whether the fluvio-estuarine sandstone is locally developed (narrow box) or regionally developed (wide box; Rice \& Hiett, 1994 and this study).

Fig. 3. Detailed maps illustrating the locations of sedimentary logs and photomosaics used to construct Fig. 5. (a) U.S. Route 119 between Pikeville and Belfry, Pike County. (b) Kentucky Route 7 between Viper and Jeff, Perry County. (c) Kentucky Route 15 between Jackson and Vancleve, Breathitt County. USGS quadrangle names marked. See Fig. 1 for the basin-scale location of the three study areas.

Fig. 4. Examples of photographs and architectural sketches, used to construct Figs. 5 and 6. The latter are corrected for perspective. (a) Photomontage of road-cut 14, U.S. Route 119, Pike County, (b) Interpretive architectural sketch of road-cut 14, U.S. Route 119. (c) Photomontage of road cut 5, Ky. Route 15, Breathitt County, (d) Interpretive architectural sketch of road-cut road cut 5, Ky. Route 15. See Fig. 3 for location of these road cuts.

Fig. 5. Correlation panels illustrating the $\mathrm{km}$-scale facies association relationships along (a) road cuts 1-27, and (b) road cuts 28-65 on U.S. Route 119 between Pikeville and Belfry, Pike County, (c) all road cuts along Kentucky Route 7 between Viper and Jeff, Perry County, and (d) all road cuts along Kentucky Route 15 between Jackson and Vancleve, Breathitt County. The locations of road cuts are shown on Fig. 3. Letters in parentheses after road cut numbers refer to the side of the road on which the road cut is to be found. The red line shows the position of the road within the succession.

Fig. 6. Correlation panel illustrating up-dip (Kentucky Route 7 and U.S. Route 119) to down-dip (Kentucky Route 15) facies relationships over $80 \mathrm{~km}$ dip length in the Pikeville and Hyden Formations. The Frozen Sandstone, Elkins Fork Sandstone and Puckett Creek Sandstone and sand bodies $\mathrm{K}$ and $\mathrm{M}$ occur in both up-dip and down-dip sectors of the study area. The Elkins Fork Sandstone and Puckett Creek Sandstone each form regionally-developed tabular sand bodies that incise into prodelta and mouth bar strata throughout the study area, and are interpreted as palaeovalley fills throughout the study area. The Frozen Sandstone and sand bodies $\mathrm{K}$ and $\mathrm{M}$ occur as more isolated sand bodies that are strongly incisional in the distal part of the basin, but do not demonstrate a basinward facies shift in the proximal part of the basin. These are interpreted as palaeovalleys in the distal part of the basin, passing up-dip into stacked distributaries. Other sand bodies, not named for clarity, occur in the up-dip sector of the study area, but pass down-dip into thin prodelta, mouth bar and floodplain successions in the distal 
part of the basin. These sand bodies are interpreted as stacked distributary channels which thin and fine as channels bifurcate down-dip on the delta top. The schematic represents approximately $80 \mathrm{~km}$ of depositional dip.

Fig. 7. Summary composite sedimentary logs through part of the Pikeville Formation and the Hyden Formation at road-cut 34, U.S. Route 119, Pike County, and road-cuts 5 and 6, Ky. Route 15, Breathitt County (see Fig. 3 for location details). Correlation is based on the coal-seam correlation framework of Rice \& Hiett (1994). Datum is the base of the Magoffin Member (Four Corners Formation). See Fig. 8 for key.

Fig. 8. Sand body architecture representative of the three classes recognised in the Pikeville and Hyden Formations. The Elkins Fork sand body is interpreted as a palaeovalley fill at up-dip locations, e.g. at (a) U.S. Route 119, Pike County, road cut 22NW, and down-dip locations, e.g. (b) Ky. Route 15, Breathitt County, road cut 5E. The Puckett Creek Sand Body is also interpreted as a palaeovalley fill at up-dip locations, e.g. at (c) U.S. Route 119, Pike County, road cut 45NW, and down-dip locations, e.g. (d) Ky. Route 15, Breathitt County, road cut 5E. Sand Body "K" is interpreted as a succession of stacked distributary channels at up-dip locations, e.g. (e) U.S. Route 119, Pike County, road cut 14SW, but as a palaeovalley-fill at down-dip locations, e.g. (f) Route 15, Breathitt County, road cut 5E. Sand Body "M" is also interpreted as a succession of stacked distributary channels at up-dip locations, e.g. (g) Ky. Route 7, Perry County, road cut 5NW, but as a palaeovalley-fill at down dip locations, e.g. (h) Sand Body "M", Ky. Route 15, Breathitt County, road cut 5E. A succession of sand bodies occur between the Whitesburg coal zone and the upper coal of the Fire Clay coal zone at up-dip locations, e.g. (i) U.S. Route 119, Pike County, road cut $14 \mathrm{SE}$. These are interpreted as stacked distributaries andare absent at downdip locations, e.g. (j) Ky. Route 15, Breathitt County, road cut 5E, being replaced by a succession of small scale delta plain and mouth bar coarsening-up packages. See Figs. 3 and 5 for location details.

Fig. 9. Cartoon depicting plan view changes in depositional and degradationial (erosional) areas and environments in the study area at selected intervals during a single cycle of eustatic sealevel rise and fall. Note that the precise scale and geomorphology of the fluvial and deltaic elements, and the size of the basin are not accurate. (a) Time of maximum rate of sea-level rise. (b) Sea-level maximum stillstand. (c) Time of maximum rate of sea-level fall (d) Sea-level minimum stillstand. See text for explanatory details. 
1146 Table 1. Summary of the characteristics of the facies associations recognised in the Pikeville

1147 and Hyden Formations in the current study. Bioturbation proportion is given according to the

1148 Bioturbation Index (BI) of Taylor \& Goldring (1993) and MacEachern (2010).

1149

1150 Supplementary Material Table 1. Details of coal exploration boreholes used to construct the

1151 isopach map for the Pikeville and Hyden formations in Fig. 1. The coal exploration boreholes are

1152 searchable via the Kentucky Geological Survey online geological data repository at

1153 http://www.uky.edu/KGS/. The position of the top and base of the Pikeville and Hyden

1154 formations were identified in each borehole using the criteria outlined by Chesnut (1992), and a

1155 structural contour map created for these surfaces using ArcGIS. The isopach map shown in Fig.

11561 was created by subtracting the structural contour map of the base of the Pikeville Formation

1157 from the structural contour map of the base of the Hyden Formation in ArcGIS. 